\title{
Prospect of Fuelwood Plantations for Marginal Small Tea Farmers: A Case Study in Matara and Badulla Districts, Sri Lanka
}

\author{
Indika Rohan Plaihakkara1,2, Abrar J. Mohammed2, Ganesh P. Shivakoti2,3, Makoto Inoue ${ }^{2}$ \\ ${ }^{1}$ Department of Crop Science, Faculty of Agriculture, University of Ruhuna, Matara, Sri Lanka \\ ${ }^{2}$ Department of Global Agricultural Sciences, Graduate School of Agricultural and Life Sciences, \\ The University of Tokyo, Tokyo, Japan \\ ${ }^{3}$ School of Environment, Resources and Development, Asian Institute of Technology, Bangkok, Thailand \\ Email: irpalihakkara@gmail.com
}

Received 4 November 2015; accepted 14 December 2015; published 17 December 2015

Copyright (C) 2015 by authors and Scientific Research Publishing Inc.

This work is licensed under the Creative Commons Attribution International License (CC BY). http://creativecommons.org/licenses/by/4.0/

(c) (i) Open Access

\section{Abstract}

This study demonstrates the importance of conversion of tea farms in marginal land to fuelwood plantation by analyzing the current biophysical, economic and institutional pros and cons of each land uses for marginal small tea plantation holders (MSTH). The study is based on household survey and field investigation conducted in Matara and Badulla Districts of Sri Lanka. Both qualitative and quantitative data on important biophysical, economic and institutional factors was collected from a total of 81 MSTH, 50 from Matara and 31 from Badulla, and fuelwood consuming industries within $20 \mathrm{~km}$ of the study area. The result showed that MSTH are facing biophysical and economic problems that are forcing them to leave portion of their tea planation land uncultivated. With ongoing demand increase for fuelwood, presence of tree species already adaptable to the area and favorable property right condition, conversion of the existing marginal land to fuelwood plantation is a viable way to sustainably manage the MSTH farmland. This will also contribute to tackle environmental disasters the area is frequently facing due to abandoning of the marginal tea plantation land.

\section{Keywords}

Sustainable Land Use, Marginalization, Tea Industry, Fuelwood, Sri Lanka 


\section{Introduction}

Sustainable land management is an integral part of harmonizing economic benefit from and environmental condition of a given land. In most developing countries, agriculture is expected to continue to be an engine of economic development [1]. To be sustainable, however, agriculture land management has to be increasingly more productive, more economically efficient and more environmentally friendly [2]. Although sustainability will continue to be elusive, assessing current land uses managements in terms of important factors for sustainability is vital for betterment of current and future generation [3]. The task is more important when considering sustainable agricultural activities conducted on marginal lands [4]. Especially considering that such marginal lands can be utilized for growing economically beneficial crops such as fuelwood whereas productive lands can be reserved for planting high valued food crops [5].

In Sri Lanka, the 2007 National Agricultural Policy identifies agricultural sector to play an important role in the country's economy and emphasizes the importance of conserving the environment and mitigate GHG emissions through increasing the tree cover and carbon sequestration [6]. Among the agriculture crops, tea is the number one economically important crop. Initially, tea plantations were predominantly owned and managed by large scale private individuals and corporates. With the growing demand in international markets for tea, the area expanded further into forest and other suitable lands in the high lands and low lands of south western Sri Lanka. The introduction of the 1972 land reform Act, No. 1 that imposed ceilings on land size of private land ownership and amendment act No 39 of 1975 that nationalized companies and distributed land to landless households created pathway for proliferation of small-holder tea farmers [7].

Currently small-holders constitute $60 \%$ of the total 212,700 ha of Sri Lankan tea farm area (TSHDA 2012), making them the major contributors for the tea industry. However, sizeable portion of the small tea farm holders are facing problem, namely marginalization of tea land. According to Ministry of Plantation Industries, marginal tea plantations are tea production lands with yield below the national average tea yield. Marginal small tea farm holders (MSTH) face problems such as low income from the tea sector [8]. There are evidences, but very limited, pointing to the unsustainability of MSTH land uses. For example, according to Dissanayake [9], tea bushes belonging to most of the tea plantations were planted more than 40 to 60 years ago with no new planting since then. Census taken in 2005 further strengthened the above argument by pointing that about 7310 hectares of the small holder plantations were abandoned.

When the existing land use is unsustainable, land use conversion from unutilized or underutilized land use to economically profitable and environmentally sound ventures provide better results for the farmers as well as the country. However, except for limited number of researches including Dissanayake [9] and Palihakkara et al. [8], there is lack of information on current condition of the MSTH land use and potential of alternative land uses to make their land use economically profitable and environmentally viable. This paper is intended to fill this knowledge gap by analyzing the current biophysical, socio-economic and institutional pros and cons of tea planting and fuelwood planation for the MSTH.

\section{Research Method}

\subsection{Study Site and Sample Selection}

Since our objective is to explore the physical, economic and institutional situation of MSTH, we set three criteria to make our research focused on locations of importance while also making it representative. The criteria are representation of both highland and lowland tea farming areas; locations where tea farm is main source of livelihood and have large number of MSTH. Based on these, Matara and Badulla Districts which represent lowland and highland tea plantation of the country respectively were selected for the study. After preliminary discussion with staffs of Tea Small Holding Development Authority (TSHDA) regional officers of the two districts, MSTH from Urubokka, Haliella, Lunugala, and Ella TSHDA sub divisions were selected for the study as they have relatively large number of MSTH. Urubokka is a TSHDA sub division in Matara District, while Haliela, Lunugala, Ella are TSHDA sub divisions in Badulla District. Urubokka is situated, North East border of Matara District, adjoining Hambantota and Rathnapura districts. Haliela is situated south western part of Badulla District while Lunugala and Ella are found in the border of Badulla District adjoining to Moneragala district (Figure 1). The study site in Matara is characterized by hilly topography with annual average rainfall below $2000 \mathrm{~mm}$ and annual average day time temperature ranging between $27^{\circ} \mathrm{C}-34^{\circ} \mathrm{C}$ with two drought periods per year (District 


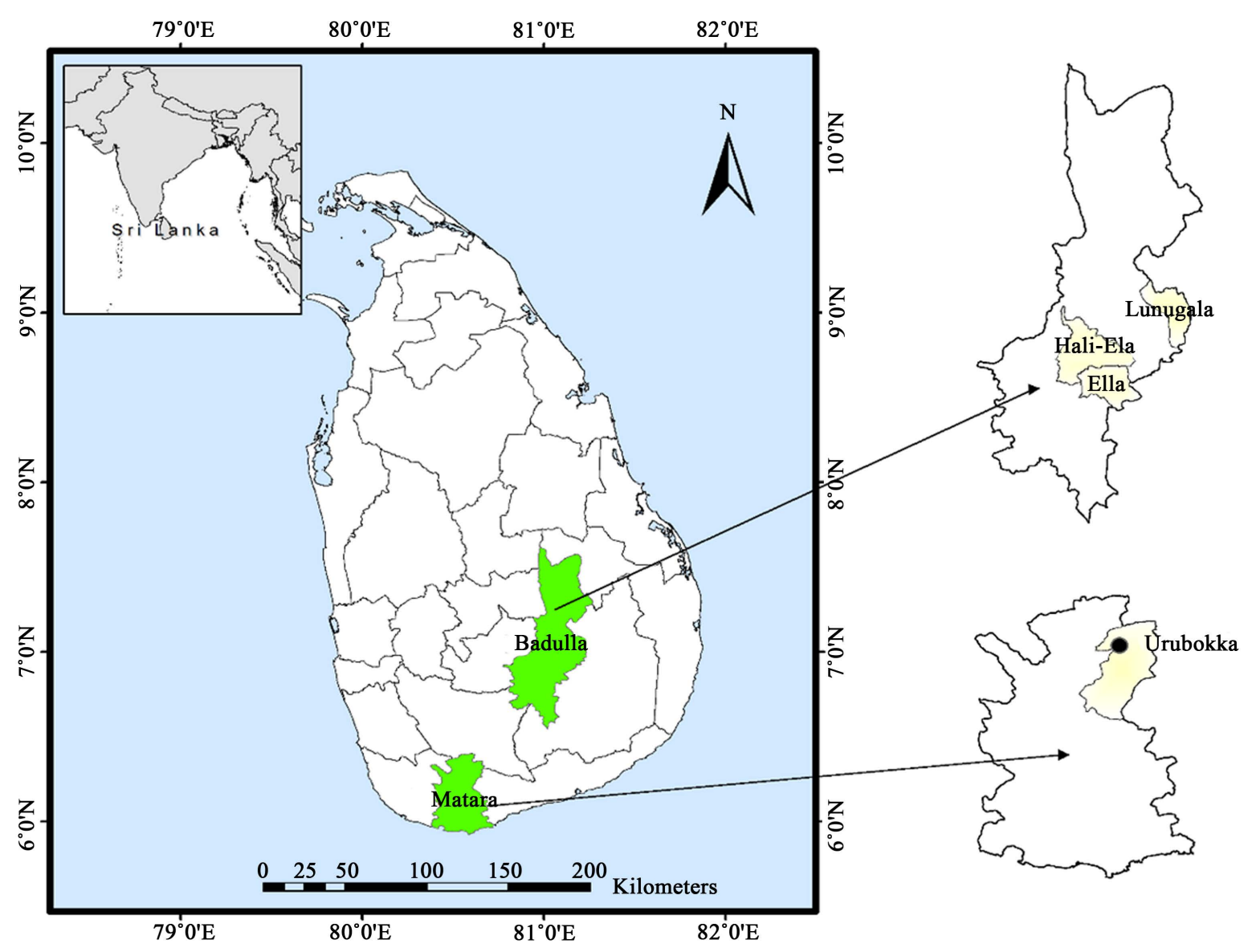

Figure 1. Location of Sri Lanka and the study sites Matara and Badulla Districts in Sri Lanka.

Secretary report Matara 2013). The study site in Badulla is also characterized by hilly topography with annual average rainfall between $1500-1900 \mathrm{~mm}$, annual average day time temperature between $18^{\circ} \mathrm{C}-33^{\circ} \mathrm{C}$ and with two identical drought periods per year (Badulla District Secretary report 2014 and DOA 2012). Most of the tea plantations in Badulla District is with seedling tea (age over 60 years) and the rest of the plantations are vegitatively propagated (VP) and more than 25 years old. In Matara District majority of the plantations are VP plantations with aging more than 25 years. These plantations are managed by the farmers with their family labour, and if family labour is not sufficient farmers hire labour for harvesting, and other plantation management activities.

From a total of 648 and 177 MSTH that were identified from Matara and Badulla District respectively, 50 MSTH for Matara and 31 MSTH for Badulla were randomly selected for data collection. Based on land size classification of TSHDA, the selected farmers were categorized into four land class, i.e., very small land holders (VSLH) ( $<1$ ha), small land holders (SLH) (1 - 2 ha), middle land holders (MLH) (2 - 3 ha), large land holders (LLH) ( $>3 \mathrm{ha}$ ). The total number of sampled farmer for VSLH, SLH $<$ MLH $<$ LLH for Matara and Badulla were $32,8,8,5$ and $8,8,5,10$ respectively.

Fuelwood end users in these two study sites were identified by referring to the records maintained by the divisional secretariat officers (D. S Office) in the study areas. Tea factories and small to medium scale bakeries were identified as major fuelwood consumers and were selected for the investigation. All the targeted fuelwood end users were selected within the $20 \mathrm{~km}$ distance, a maximum recommended distance to collect green tea leaves from the growers to the tea processing factories.

\subsection{Data Collection}

Data was collected using interviews, archival record reviews and field observation. Initially, review of archival records such as field records as well as reconnaissance survey of the research site together with TSHDA officer in 
charge of the area was conducted. A pre-tested structured and semi structured questionnaire interview as well as field observation were conducted to collect biophysical, socio-economic and institutional data including income, type of property right, number of trees, slope, age of the tea crop, area of uncultivated areas inside the plantation with a potential to plant timber/fuelwood trees and reasons for keeping uncultivated areas in their plantation. The data were collected from beginning of February to early September, 2014. The quantitative data was summarized through descriptive statistics such as average and percentile using excel.

\section{Result and Discussion}

\subsection{Physical Attributes}

The most important biophysical factors for sustainability of the tea farm were found to be slope, soil, presence of shade trees and accessibility of the plantation from main road. Our data showed that the average slope ranged from 48\% - 53\% in Matara and from 49\% - 61\% in Badulla. In both Matara and Badulla Districts, farmers belonging to the MLH category have the highest percentage slope at $53 \%$, and $61 \%$ respectively. All the slope categories of both districts are in the upper levels of moderately suitable lands of TRI's land suitability classification for tea except for MLH in Badulla that is in the severe category with a slope of $61 \%$. In Matara, all households except VSLH category have mentioned that the slope had negative impact in the productivity of their tea farming (Table 1).

In addition to the slope, the rocky nature of the ground they are farming was also found to have strong impact on the productivity of their farm. Except for the SLH category, more than $60 \%$ of the interviewees mention rocky soil as important reason for marginalization of their farm land (Table 1). This probably is also related to the slope of the area which made it susceptible for serious erosion. As discussed under implication for sustainability, the area is commonly affected by soil erosion and landslide.

The final important physical attribute is the location of the plantation. In order to be economically feasible and minimize the cost of transportation, it is better if tea plantation is located in the upper side of the accessible road. If accessible road is far away from the production site the produce have to be carried up to the last point where the vehicle may reach, local farmers have to use either human or animal power for the local transportation inside their plantation [10]. However, we observed that in both districts, irrespective of the land size, more than half of the plantations are located towards the lower side of the road (Table 1).

As witnessed by the current coverage, the area can grow different tree species that can be used for fuelwood and other purposes. We have found already well established twelve tree species, two in both district, six in Badulla alone and four in Matara alone. The stocking of these trees range between 0.5 - 30.2 tree/ha. These trees are important source of fuelwood and other goods and services. The most dominant species is fast growing medium shade tree species called Gliricidiasepium. This species is also used for fuelwood, fodder, green manure and insecticide. Out of the eight species, only four of them (marked by * in Table 2(b)) are recommended by TRI. However, the accessibility of the site (Table 1) still remain a major problem for future benefit extraction from fuelwood because of reduction of the value of these bulky products such as fuelwood due to relatively higher cost for local handling or heaping inside the plantation [11].

\section{Table 1. Physical attribute of the study site and perception of its impact on tea farming.}

\begin{tabular}{|c|c|c|c|c|c|c|c|c|}
\hline \multirow{2}{*}{ Physical attribute } & \multicolumn{4}{|c|}{ Matara District (farmers) } & \multicolumn{4}{|c|}{ Badulla District (farmers) } \\
\hline & VSLH & SLH & MLH & LLH & VSLH & SLH & MLH & LLH \\
\hline Slope percentage & 48 & 48 & 53 & 49 & 49 & 54 & 61 & 52 \\
\hline Perception on negative impact of slope (\%) & 41 & 62 & 100 & 80 & 37 & 37 & 40 & 80 \\
\hline Perception of negative impact of rocky soil (\%) & 78 & 80 & 80 & 80 & 62 & 37 & 80 & 80 \\
\hline Planation located in the lower side of the road & 62 & 58 & 55 & 65 & 56 & 58 & 52 & 59 \\
\hline Planation located in the upper side of the road & 35 & 38 & 42 & 30 & 32 & 29 & 37 & 26 \\
\hline Planation located in the middle of the road & 03 & 4 & 03 & 05 & 22 & 13 & 11 & 15 \\
\hline
\end{tabular}


Table 2. (a) Number of tree in the study sites; (b) type of species found in the tea farmland.

(a)

\begin{tabular}{ccccccccc}
\hline \multirow{2}{*}{ Tree } & \multicolumn{3}{c}{ Matara District (farmers) } & \multicolumn{4}{c}{ Badulla District (farmers) } \\
\cline { 2 - 8 } & VSLH & SLH & MLH & LLH & VSLH & SLH & MLH & LLH \\
\hline Number of high shade trees ${ }^{1}$ & 178 & 42 & 141 & 26 & 119 & 104 & 193 & 384 \\
Number of medium shade trees & 1628 & 160 & 720 & 450 & 340 & 205 & 655 & 1100 \\
\hline
\end{tabular}

(b)

\begin{tabular}{|c|c|c|c|c|c|c|c|c|}
\hline Species name & $\begin{array}{l}\text { Total no. } \\
\text { of trees }\end{array}$ & $\begin{array}{c}\text { No. of } \\
\text { farmers (\%) }\end{array}$ & $\begin{array}{l}\text { Land } \\
\text { area }\end{array}$ & Tree/ha & $\begin{array}{l}\text { Total no. } \\
\text { of trees }\end{array}$ & $\begin{array}{c}\text { No. of } \\
\text { farmers (\%) }\end{array}$ & Land area & Tree/ha \\
\hline Gliricidia sepium $^{*}$ & 2958 & $34(68)$ & 97.8 & 30.2 & 1370 & $15(48)$ & 73.76 & 18.6 \\
\hline Erythrina lithosperma* & 0 & 0 & 0 & 0 & 580 & $9(29)$ & 64.4 & 9 \\
\hline Grevillea robusta* $^{*}$ & 0 & 0 & 0 & 0 & 437 & $21(68)$ & 142.31 & 3.1 \\
\hline Calliandra calothrysus ${ }^{*}$ & 0 & 0 & 0 & 0 & 350 & $5(10)$ & 19.4 & 18 \\
\hline Swietenia mahogany & 93 & $8(16)$ & 35.4 & 2.6 & 118 & $7(23)$ & 71.9 & 1.6 \\
\hline Michelia champaca & 0 & 0 & 0 & 0 & 100 & $19(61)$ & 135.4 & 0.7 \\
\hline Eucaliptas spp. & 0 & 0 & 0 & 0 & 87 & $15(48)$ & 136.3 & 0.6 \\
\hline Toona sinensis & 0 & 0 & 0 & 0 & 58 & $11(35)$ & 123.5 & 0.5 \\
\hline Albizia moluccana ${ }^{*}$ & 138 & $17(34)$ & 30.3 & 4.6 & 0 & 0 & 0 & 0 \\
\hline Chloroxylon swietenia & 6 & $1(2)$ & 0.94 & 6.3 & 0 & 0 & 0 & 0 \\
\hline Artocarpus hetorophyllus & 59 & $7(14)$ & 12.61 & 4.7 & 0 & 0 & 0 & 0 \\
\hline Milia azadirach & 184 & $23(46)$ & 57.68 & 3.2 & 0 & 0 & 0 & 0 \\
\hline
\end{tabular}

${ }^{1}$ High shade trees are trees that naturally grow taller than $10 \mathrm{~m}$ with spreading crown while medium shed tree grow only up to $10 \mathrm{~m}$ in height with moderate to small crown diameter.

\subsection{Economics of Tea Farming and Fuelwood Production}

For understanding the economics of tea framing, we concentrated on income given that tea is a cash crop. As shown in Table 3, in Badulla, income from tea contribute less than a quarter of the total income of the farmers. The figure gets better for Matara but still less than half of the total incomes are from tea farming. The total percentage of farmers getting income from tea farming is also less than half except for the SLH group in both district and MLH group in Matara District. Hence, it can be concluded that currently tea production is not contributing significantly for these marginal small farm holder considering that tea was supposed to be the dominant income source of these farmers.

Fuelwood is the major source of energy for cooking in both study sites. According to data from Department of Census and Statistics (2009/2010), 87.6\% and 95.9\% of the people in Southern province including Matara District and Uva Province including Badulla District use fuelwood as major source of energy for cooking. The figure is higher than the country average which is $80.5 \%$. Furthermore, many industries such as agro-industry (tea, rubber, coconut, processing), manufacturing industry (brick, tile, lime etc.), and certain establishments in the commercial sector (bakery, hotel, eating houses, etc.) use biomass mainly from fuelwood for processing and drying. There are also a number of small scale industries which use bio-energy, includes pottery, ceramic, chemical, metal, textile, distilleries, crop \& fish drying, laundries, paddy parboiling, etc. [12]. The tea industrial sector is the largest fuelwood user in the country consuming about 33\%, of the country fuelwood production [13]. In the process of tea drying in Sri Lanka more than 95\% of the energy requirement is thermal energy and most of this energy (85\%) is, obtained from fuelwood [14]. 
Table 3. Relative and total income from tea farming (Rs/ha/year).

\begin{tabular}{ccccccc}
\hline \multirow{2}{*}{$\begin{array}{c}\text { Farmer } \\
\text { category }\end{array}$} & Income & $\begin{array}{c}\text { Percentage of } \\
\text { total income } \\
\text { contribution }\end{array}$ & $\begin{array}{c}\text { Percentage of } \\
\text { farmers generating } \\
\text { income (only from tea) }\end{array}$ & $\begin{array}{c}\text { Income } \\
\text { (Sri Lanka } \\
\text { Rupees) }\end{array}$ & $\begin{array}{c}\text { Percentage } \\
\text { total income } \\
\text { contribution }\end{array}$ & $\begin{array}{c}\text { Percentage of } \\
\text { farmers } \\
\text { generating income } \\
\text { (only from tea) }\end{array}$ \\
\hline VSLH & 54,462 & 27 & 38 & 57,471 & 45 & 43 \\
SLH & 59,276 & 32 & 50 & 54,336 & 52 & 50 \\
MLH & 36,572 & 23 & 20 & 73,419 & 31 & 80 \\
LLH & 26,681 & 14 & 30 & 28,023 & 8 & 40 \\
\hline
\end{tabular}

*1 USD = 130 Sri Lanka Rupees, 2014.

Home gardens, crop plantations mainly with (rubber, tea , coconut), and manmade forests supply major portion of biomass requirement of the country and is mostly used "as-it-is" instead of converting it in to other forms such as charcoal. The major sources of fuelwood in the study area are from home garden, state controlled fuelwood sources from State Timber Corporation (STC) and tea plantations. While the total production of tea has increased from 291 million kg in 2008 to 338 million kg in 2014 (Annual reports of Sri Lanka Tea Board and Tea market review 2014), state controlled fuelwood supply from STC have been more or less stable except for some years. This shows that the STC are now increasing their supply to make up for the increased production of tea.

In addition, the fuelwood price continue to increase reflecting the gap in demand and supply (Table 4). Both fuelwood suppliers and end users interviewed in this research unanimously agreed that the fuelwood price showed increment compared to previous years. Our data also show an increment in price of fuelwood between $9 \%$ - $40 \%$ depending on the species type.

However, when we assess the current contribution of tea plantations for tea industry fuelwood demand in the study sites, they only constitute 4\% of the total supply in Matara, the figure getting better for Badulla with $23 \%$ (Table 5(a)). The major source for fuelwood supply covering $87 \%$ and $73 \%$ in Matara and Badulla respectively is home gardens. The fuelwood supply from tea plantations for bakery and other medium to small scale industry (cottage industries) was also found to be small with 3\% and 11\% in Matara and Badulla respectively (Table 5(b)). Here also, home garden was the major source of fuelwood. Hence we can conclude that there is a demand for fuelwood and the current contribution from tea plantations is very small.

\subsection{Institutions}

Secured property right has been identified as one of the most important factor for local people's investment decision on natural resource management such as tea planation and fuelwood. In the study site, six different types of property right permits under government land allocation programs were identified. These are deeds, LDO permission, Government temporary permits, Government Agent (GA) and Divisional Secretory (DS) permits, Letter from Government Agent (GA) and other category government permission. Farmer with land deeds have full legal authority to utilize the land in terms of planting crops, trees, sell or transfer the whole land or part of the land to another person (only to a Sri Lankan not for a foreigner). However he or she has to follow the prevailing rules and regulations of felling and transporting of the timber trees listed by the government. LDO permission holders also can utilize the land for planting crops, trees, construction of their houses but cannot sale it. LDO permit holders have also to follow the prevailing rules and regulations of felling and transporting of the timber trees listed by the government. The difference with deed holders is that for LDO permits, holders have to follow lengthy procedure, to get cutting and transporting permits.

Government temporary permits issued by the District Land commissioner is a permit issued prior to issue original LDO permission and these land holders enjoy the land property rights as mentioned under the LDO permits except that they cannot get Property Loans through banks. Government Agent (GA) and Divisional Secretary (DS) permit holders can utilize the land only for agricultural activity (planting crops and trees) and construct a house (permanent). They cannot cut the listed trees by the government inside their land and it is very difficult to get transporting permits. If the householders really need to remove or cut the trees, they have to get special permit from the GA or DS. Like Government temporary permits, they cannot get Property Loans through 
Table 4. Average fuelwood price during 2012-2014 in the area $\left(\mathrm{Rs}^{*} / \mathrm{m}^{3}\right)$.

\begin{tabular}{ccccccccc}
\hline \multirow{2}{*}{ Species } & \multicolumn{3}{c}{ Matara } & \multicolumn{3}{c}{ Badulla } \\
\cline { 2 - 9 } & 2012 & 2013 & 2014 & Increment (\%) & 2012 & 2013 & 2014 & \% Increment \\
\hline Rubber & 1000 & $\mathrm{Na}$ & 1200 & 20 & 2000 & $\mathrm{Na}$ & 2300 & 15 \\
Jungle & 825 & 875 & 900 & 9 & 1316 & 1700 & 1800 & 37 \\
Gliricidia & 775 & 800 & 900 & 16 & 1200 & 1650 & 1700 & 42 \\
Albizia & 625 & 700 & 750 & 12 & $\mathrm{Na}$ & $\mathrm{Na}$ & $\mathrm{Na}$ & \\
Eucalyptus spp. & $\mathrm{Na}$ & $\mathrm{Na}$ & $\mathrm{Na}$ & & 1600 & 1850 & 1900 & 19 \\
Acasia spp. & $\mathrm{Na}$ & $\mathrm{Na}$ & $\mathrm{Na}$ & & 1150 & 1533 & 1600 & 39 \\
Mango/cashew & $\mathrm{Na}$ & $\mathrm{Na}$ & $\mathrm{Na}$ & & 1250 & 1500 & 1600 & 28 \\
Other/mixed & 675 & 800 & 800 & 18 & 1250 & 1733 & 1750 & 40 \\
\hline
\end{tabular}

${ }^{*} 1$ USD = 130 Rs (Sri Lanka Rupees), 2014.

Table 5. (a) Monthly fuelwood supply to tea factories from different fuelwood suppliers; (b) monthly fuelwood supply to cottage industries from different fuelwood suppliers.

(a)

\begin{tabular}{ccccc}
\hline \multirow{2}{*}{ Fuelwood source } & \multicolumn{2}{c}{ Matara } & \multicolumn{2}{c}{ Badulla } \\
\cline { 2 - 5 } Tea plantations & Volume $\left(\mathrm{m}^{3}\right)$ & Supply $(\%)$ & Volume $\left(\mathrm{m}^{3}\right)$ & Supply (\%) \\
\hline Home gardens/other agric. lands & 17.46 & 4 & 98.46 & 23 \\
STC & 322.95 & 85 & 303.79 & 73 \\
Total & 41.3 & 11 & 15.4 & 417.67 \\
\hline
\end{tabular}

(b)

\begin{tabular}{ccccc}
\hline Tea plantations & 9 & 3 & 25 & 11 \\
\hline Home gardens/other agric. lands & 242.42 & 90 & 786.2 & 83 \\
STC & 17.2 & & 7 & 225.2 \\
Total & & 268.6 & & 6 \\
\hline
\end{tabular}

banks. Letter from Government Agent holders too can only utilize the land for agricultural activities, and construct temporally houses but cannot cut or transport timber trees listed by the government or get Property Loans through banks. Moreover, any time the government can decide to cancel the letter issued by the GA. Finally, there are also other category of government permission but of less important. People with these permissions also have similar bundles of property right as Government temporary permits. Deeds provide strongest property right followed by LDO permission, Government Agent and Divisional Secretory permits, letter from Government Agent, other category government permission, and government temporary permits.

Since both tea and fuelwood plantations are a long term investment, they both need secured property right. Hence, insecure or short period property right permit are expected to affect both. The effect, however, might be stronger on willingness to establish fuelwood planting as it relatively takes longer period as compared to tea plantation to generate income from it. As shown in Table 6, most of the households in both district have either deeds or LDO permits, the two permits that give strongest property right over land. Although the total percentage of farmers without any legal document is small, the one without any legal document constitute the very small and small land holdings (Table 6). 
Table 6. Percent of land ownership according to four different land categories of the MSTH.

\begin{tabular}{|c|c|c|c|c|c|c|c|c|c|c|c|c|c|c|}
\hline \multirow{2}{*}{ Category } & \multicolumn{7}{|c|}{ Matara } & \multicolumn{7}{|c|}{ Badulla } \\
\hline & $\mathrm{DD}$ & LDO & GAT & GA/DS & GAL & OL & NL & $\mathrm{DD}$ & LDO & GAT & GA/DS & GAL & OL & NL \\
\hline (VSLH) & 12.5 & 34 & 19 & 12.5 & 9 & 3 & 9 & 12.5 & 25 & 25 & 12.5 & 12.5 & 0 & 12.5 \\
\hline (SLH) & 25 & 25 & 12.5 & 12.5 & 12.5 & 0 & 12.5 & 37.5 & 12.5 & 12.5 & 12.5 & 0 & 0 & 25 \\
\hline$(\mathrm{MLH})$ & 40 & 40 & 0 & 0 & 0 & 0 & 20 & 20 & 20 & 20 & 0 & 20 & 0 & 20 \\
\hline$(\mathrm{LLH})$ & 80 & 20 & 0 & 0 & 0 & 0 & 0 & 60 & 20 & 10 & 10 & 0 & 0 & 0 \\
\hline
\end{tabular}

Note: DD (Deeds), LDO (Land Development Ordnance), GAT (Government temporally permits), GA/DS (Government Agent/Divisional Secretory permits), GAL (Letter from Government Agent), OL (other category government permission), NL (Without any legal document).

\section{Discussion}

Most farmers in developing nations depend on natural resource for their livelihoods [15] [16]. Hence, it is apparent that sustainable land use conversion from any type of unutilized or underutilized crop lands to economically profitable and environmentally sound ventures provide better results for these farmers. As shown in the result section, the economic benefit from marginal tea farm lands is meager. Consequently, farmers' are forced to leave about 6\% (SLH in Badulla) to 30\% (LLH in Badulla) their farmland uncultivated. Physical factors such sloppy topography, frequent soil erosion, landslides and rocky soil have made tea planting difficult. In addition, once farmers' plant tea in these areas, its growth rate is slow making investment on it economically unattractive. Hard rocks, above ground as well as shallow top soil severely affects root system of the tea plants especially during the drought period. Even with the available subsidy schemes introduced by the government through TSHDA, farmers and officers explained the earlier replanting and new planting practices failures experienced by the farmers. With current slope and ongoing soil erosion further reducing the depth of the top soil, it is forcing farmers to completely give up managing these marginal areas [17].

Such kind of land marginalization is not a sole problem of Sri Lanka, rather it is also common throughout the world. A global study conducted using satellite images estimated that there are 430 to 580 million ha abandoned or marginalized agricultural lands [17]. One viable option commonly recommended for sustainable utilization of these areas is to use them for bioenergy production. According to Campbell et al. [18], if proper utilization of these lands in all over the world to a bioenergy production (above ground bio mass), would provide $2 \%$ to $23 \%$ of the world primary energy demand. The demand for bioenergy such as fuelwood is also increasing. For example, fuelwood usage and the future projected demand from 1970 to 2020 for south Asia showed to increase from 234 to 361 million cubic meters respectively [19].

Energy producing plants or mainly fuelwood producing trees give promising renewable energy that could reduce the industries totally or partially depend on fossil fuels and it is very important for the countries which do not have their own fossil fuel resources. Furthermore it will certainly help minimize greenhouse gas (GHG) emissions [20] [21]. In the future, fuelwood and energy tree growers can play a key role for supply the energy requirement while safeguarding the environmental stability. This however demands that extraction of fuelwood will be in an environmental friendly manner [22]. Overall, conversion of marginal tea plantation to fuelwood plantation will not only have local impact, but can also contribute to solving national and global environmental concerns. This, however, requires secured property right and devolution of significant decision making power on access to and utilization of the resource to MSTH in order to guarantee their investment now will bore fruit for them in the future [23]-[25].

In addition, utilizing or converting good agricultural lands into biomass productions such as fuelwood and bio gas/liquid fuels will certainly create ethical and controversial problems to the world food production and will exacerbate the food price and food-insecurity problem that most developing nations are facing [26]. One possible option for fuelwood and biofuel production is utilization of low productive agriculture lands such as degraded, marginal and abandoned lands or underutilized areas. The vacant areas or in other words uncultivated areas inside the sloppy agricultural lands and tea plantations especially with slope more than $30 \%$, face soil erosion and create serious environmental problems [27]. The study site, for example, has been a frequent victim of landslide and flooding due to large section of bare uncultivated land. These uncultivated areas can be utilized to cultivate other income generating nonfood crops which are well adapted to harsh local conditions and it will certainly increase the living slandered of the local people [28]. 
Gliricidia species is a promising candidate for establishment of such planation as it is the most common species in the study site (Table 3 and Table 5). Even though Acasia, Mango and Cashew trees are used as fuelwood in tropical areas of the world [29], end users preference of these three species in our study were found to be low because of low calorific values and negative effect on the quality of the end product, i.e. tea. The second candidate species is rubber as it is the most preferred species by end users in two districts. This is mainly because of its properties such as relatively high caloric value, easy to burn and no need to applying transporting permits [30]. For the producers, this might also be an attractive option as it has higher unit price than other fuelwood types.

\section{Conclusions and Implications}

The result from this study shows that Marginal small tea farm holders (MSTH) in Matara and Badulla Districts have biophysical and economic constraints which are forcing them to leave part of their land uncultivated. The slope of the area ranges from $48 \%$ - 53\% in Matara and from $49 \%$ - 61\% in Badulla. Moreover, more than $60 \%$ of the interviewees mentioned rocky soil as important reason for marginalization of their farm land. Consequently, despite being the main land use, tea planation generates only less than a third of the total households' income. Because of this, farmers are leaving up to $30 \%$ of their land uncultivated. These uncultivated lands, amplified by the slope of the area, is leading to frequent soil erosion and land slide.

There are many advantages of converting these lands into fuelwood planation. Biophysically, there are already well adapted tree species that can be used for establishing planation. Twelve tree species that are already growing in this marginal area were identified by this study. These species can be used to establish plantations. Moreover, other species that have high demand such as rubber can also be recommended. The high market for and the ongoing increase in price of fuelwood provides economic confidence to enter into this venture. For example, the price of the most dominant tree species, i.e. Gliricidiasepium, has recently increased by $42 \%$. The present market share of fuelwood from tea planation, however, is very low, with less than $5 \%$ in Matara and $25 \%$ in Badulla. Another opportunity for covers ion of marginal farm land to fuelwood plantation is the existing property right system. Most of the small holders have either land deed or L.D. permits that give strong property right on land for the tea farmers. Planting trees will also protect the land users from frequent flooding, soil erosion and land slide that they are facing now.

Our study has two implications, the first one is methodological and the other one is policy implication. For the former, we combined socio-economic data with agronomic practices together with biophysical attributes of the land to have a comprehensive understanding of the MSTH farming system. This is particularly important in the study of sustainability as such studies cross academic discipline boundaries. The policy implication of the study is that government should promote or provide incentives for farmers to convert such degraded and abandoned land into fuelwood plantations. Sri-Lanka already has experience with financial and institutional incentives to motivate farmers' practice of beneficial land use. Such experiences can be utilized to design policy incentives for MSTH too.

\section{Acknowledgements}

The authors thank and acknowledge partial financial support from Grants-in-Aid for Scientific Research (A) supported by the Government of Japan (No. 24248026, Project leader: Makoto Inoue). The finding, however, does not represent the views of the Japanese Government.

\section{References}

[1] Timmer, C.P. (2002) Handbook of Agricultural Economics Chapter 29. Agriculture and Economic Development, 2, 1487-1546.

[2] Garnett, T., Appleby, M.C., Balmford, A. and Bateman, I.J. (2013) Sustainable Intensification in Agriculture: Premises and Policies. Science, 341, 33-34. http://dx.doi.org/10.1126/science.1234485

[3] Tscharntke, T., Clough, Y., Wanger, T.C., Jaxckson, L., Motzke, I., Perfecto, I., Vandermeer, J. and Whitbread, A. (2012) Global Food Security, Biodiversity Conservation and the Future of Agricultural Intensification. Journal of Biological Conservation, 151, 53-59.

[4] Gelfand, I., Sahajpal, R., Zhang, X., Izaurralde, R.C., Gross, K.L. and Robertson, G.P. (2013) Sustainable Bioenergy Production from Marginal Lands in the US Midwest. Nature, 493, 514-517.

[5] Plieninger, T. and Gaertner, M. (2011) Harnessing Degraded Lands for Biodiversity Conservation. Journal of Nature 
Conservation, 19, 18-23. http://dx.doi.org/10.1016/j.jnc.2010.04.001

[6] Ranasinghe, D.M.H.S.K. (2012) Climate Change Mitigation, Sri Lankas Perspective. Proceedings of International Forestry and Environment Symposium, 15, 290-296.

[7] Peiris, G.H. (1978) Land Reform and Agrarian Change in Sri Lanka. Journal of Modern Asian Studies, 12, 611-628. http://dx.doi.org/10.1017/S0026749X0000634X

[8] Palihakkara, I.R., Mohammed, A.J. and Inoue, M. (2015) Current Livelihood Condition of and Futurity of Tea Farming for Marginal Small Tea Farm Holders (MSTH) of Sri Lanka: Case Study from Badulla and Matara District. Journal of Environment and Natural Research, 5, 11-21. http://dx.doi.org/10.5539/enrr.v5n1p11

[9] Dissanayake, D.R.R.W., Udugama, J.M.M. and Jayasinghe-Mudalige, U.K. (2013). Development of an Alternative Microfinance Scheme to Finance in the Tea Small Holding Sector: A Success Story. Journal of Food and Agriculture, 3, 31-40. http://dx.doi.org/10.4038/jfa.v3i1-2.5168

[10] Danso-Wiredu, E.Y. (2011) Mobility and Access for Off-Road Rural Farmers in West-Akim District Ghana. Journal of Geography, 3, 230-249.

[11] Wiggins, S. and Proctor, S. (2001) How Special Are Rural Areas? The Economic Implications of Rural Development. Development Policy Review, 19, 427-436. http://dx.doi.org/10.1111/1467-7679.00142

[12] Perera, K.K.C.K., Rathnasiri, P.G., Senarath, S.A.S., Sugathapala, A.G.T., Bhattacharya, S.C. and Salam, P.A. (2005) Assessment of Sustainable Energy Potential of Non-Plantation Biomass Resources in Sri Lanka. Journal of Biomass and Bioenergy, 29, 199-213. http://dx.doi.org/10.1016/j.biombioe.2005.03.008

[13] Haskoning (1989) Energy Conservation in the Tea Industry of Sri Lanka. Royal Dutch Consulting Engineers and Architects.

[14] Jayah, T.H. (2001) The Potential for Wood Gasifiers for Tea Drying in Sri Lanka. International Energy Journal, 2, 85-93.

[15] Mohammed, A.J. and Inoue, M. (2013) Forest-Dependent Communities’ Livelihood in Decentralized Forest Governance Policy Epoch: Case Study from West Shoa Zone, Ethiopia. Journal of Natural Resource Policy Research, 5, 49-66. http://dx.doi.org/10.1080/19390459.2013.797153

[16] Sherbinin, A., Vanwey, L.K. McSweeney, K. Aggarawal, R., Barbieri, A., Henry, S., Hunter, L.M. and Twine, W. (2008) Rural Household Demographics, Livelihoods and the Environment. Global Environmental Change, 18, 38-53. http://dx.doi.org/10.1016/j.gloenvcha.2007.05.005

[17] Humble, R. (1990) Decreasing Extent of Tea Plantations. A Chance for Agricultural Diversification or Ecological Threat. Sri Lanka Journal of Tea Science, 59, 65-81

[18] Campbell, J.E., Lobell, D.B. and Genova, R.C. (2008) The Global Potential of Bioenergy on Abandoned Agriculture Lands. Environmental Science and Technology, 42, 5791-5794. http://dx.doi.org/10.1021/es800052w

[19] Arnold, M. and Persson, R. (2003) Reassessing the Fuelwood Situation in Developing Countries. International Forestry Review, 5, 379-383. http://dx.doi.org/10.1505/IFOR.5.4.379.22660

[20] Yao, C.S., Chen, C.Y. and Li, M. (2012) Analysis of Rural Residential Energy Consumption and Corresponding Carbon Emissions in China. Energy Policy, 41, 445-450. http://dx.doi.org/10.1016/j.enpol.2011.11.005

[21] Farrel, A.E., Plevin, R.J., Turner, B.T., Jones, A.D., Hare, M.O. and Kammen, D.M. (2006) Ethanol Can Contribute to Energy and Environmental Goals. Science, 311, 506-508. http://dx.doi.org/10.1126/science.1121416

[22] Groom, M.J., Gray, E.M. and Townsend, P.A. (2008) Biofuels and Biodiversity: Principles for Creating Better Policies for Biofuel Production. Conservation Biology, 22, 602-609. http://dx.doi.org/10.1111/j.1523-1739.2007.00879.x

[23] Mohammed, A.J. and Inoue, M. (2012) Explaining Disparity in Outcome from Community-Based Natural Resource Management (CBNRM): A Case Study in Chilimo Forest, Ethiopia. Journal of Environmental Planning and Management, 55, 1248-1267. http://dx.doi.org/10.1080/09640568.2011.640171

[24] Ribot, J.C. (2002) Democratic Decentralization of Natural Resource: Institutionalizing Popular Participation. World Resource Institute, Washington DC.

[25] Mohammed, A.J. and Inoue, M. (2013) Linking Outputs and Outcomes from Devolved Forest Governance Using a Modified Actor-Power-Accountability Framework (MAPAF): Case Study from Chilimo Forest, Ethiopia. Forest Policy and Economics, 39, 21-31. http://dx.doi.org/10.1016/j.forpol.2013.11.005

[26] Tatsuji, K. and Keiji, O. (2007) Biofuels Policies in Asian Countries: Impact of the Expanded Biofuels Programs on World Agricultural Markets. Journal of Agricultural \& Food Industrial Organization, 5, 15-42.

[27] Hany, E.I.K., Zhang, H., Zhang, P. and Mosandi, R. (2013) Soil Erosion and Surface Runoff on Different Vegetation Covers and Slope Gradients: A Field Experiment in Southern Shaanxi Province, China. CATENA, 105, 1-10. http://dx.doi.org/10.1016/j.catena.2012.12.012 
[28] Newman, S.M. (1985) A Survey of Intercultural Practices and Research in Sri Lanka. Journal of Agroforestry Systems, 3, 25-36. http://dx.doi.org/10.1007/BF00045736

[29] Egeru, A., Kateregga, E. and Majaliwa, G.J.M. (2014) Coping with Firewood Scarcity in Soroti District of Eastern Uganda. Open Journal of Forestry, 4, 70-74. http://dx.doi.org/10.4236/ojf.2014.41011

[30] De Silva, W.C.A. (1994) Status Review of Energy Utilization by the Tea Industry in Sri Lanka. Sri Lanka Journal of Tea Science, 63, 46-58. 